\title{
Supplement
}

\section{Neurocritical Care Symposium}

\section{Toronto, June 1993}

The President's Symposium on Neurocritical Care was held during the XXVIII Canadian Congress of Neurological Sciences in Toronto on June 19, 1993. The symposium consisted of 5 separate talks by North American leaders in the field and a panel discussion which addressed the issues facing neurocritical care in Canada.

\author{
Neurocritical Care \\ Precis of Panel Discussion \\ Cerebral Blood Flow and Metabolism \\ Electrophysiological Monitoring in the \\ Intensive Care Unit \\ Multi-modality Monitoring in Head Injury: \\ New Insights into Pathophysiology \\ Critical Care for Guillain-Barré Syndrome \\ Assessment of Respiratory Function in the \\ Intensive Care Unit
}

$\begin{array}{ll}\begin{array}{l}\text { Bryan Young } \\ \text { Paul Muizelaar }\end{array} & \begin{array}{l}\text { Pages S3-S5 } \\ \text { Pages S6-S11 }\end{array} \\ \begin{array}{l}\text { Keith Chiappa } \\ \text { Richard Moulton }\end{array} & \begin{array}{l}\text { Pages S12-S16 } \\ \text { Allan Ropper }\end{array} \\ \begin{array}{ll}\text { Charles Bolton } & \text { Pages S23-S27 }\end{array} \\ \end{array}$

\section{ACKNOWLEDGEMENTS}

The Canadian Neurocritical Care Group wishes to express its gratitude to the following individuals and organizations: Ms. Lucile Edwards, Secretariat, the Canadian Congress of Neurological Sciences, for her assistance in planning the meeting; Dr. William McCormick, President of the Congress, who conceived of the idea of the symposium, for his support and leadership of the meeting; Miles Canada, Inc. Pharmaceutical Division (notably director, Christopher McNamara), for financial support for the meeting, guest speakers and the publication of the symposium; Dr. William Sibbald, Director of the Richard Ivey Critical Care/Trauma Centre, Victoria Hospital, London, Ontario, for his interest and participation in the panel discussion; those who attended the symposium, for their interest, excellent suggestions and comments. 